\title{
Model Based Inversion of Acoustic Impedance from Seismic Trace for Lithofacies Differentiation: an Application in Xy Field Offshore Niger Delta
}

\author{
${ }^{* 1}$ EZE, S; 1,2ORJI, OM; ${ }^{3}$ NNOROM, SL; ${ }^{3}$ UBOGUN, K \\ ${ }^{I}$ Department of Geology, University of Port Harcourt, Port Harcourt, Nigeria. \\ ${ }^{2}$ Department of Petroleum Engineering and Geosciences, Petroleum Training Institute, Effurun, Nigeria. \\ ${ }^{3}$ Department of Earth Sciences, Federal University of Petroleum Resources, Effurun, Nigeria. \\ *Corresponding Author Email: uchechukwueze2014@gmail.com
}

\begin{abstract}
This study presents the result of a Model-based seismic inversion technique which was used to invert an acoustic impedance structure within a reservoir interval by intergrating well logs and 3D post stack seismic data obtained from XY field offshore Niger Delta. The purpose was to delineate lateral and vertical alternations in subsurface rock properties which is caused by difference in lithofacies within the reservoir interval. This would help to define hydrocarbon fairways better and constrain the range of hydrocarbon zones for field development. The inversion workflow used in this study includes forward modelling of reflection coefficients from a low frequency impedance model driven from well logs and convolution of the reflection coeffiecients with a source wavelet derived from the seismic data. Acoustic impedance cross section obtained from the inversioin algorithim showed impedance values increasing from 4112 to $7539\left(\mathrm{~m} / \mathrm{sec}^{*} \mathrm{~g} / \mathrm{cm}^{3}\right)$ from top to bottom of the reservoir with gas filled sand facies observed at the top of the reservoir within time window $1900-2100 \mathrm{msec}$. Below time window $2100 \mathrm{msec}$, there is variation in impedance values observed within the anticlinal structures seen at this interval which suggests porous sand facies containing little shale intercalations. This is characteristic of sandstone reservoirs within the Agbada formation in the Niger Delta. These sands were most likely deposited through distributaries channel deposits, distributaries mouth bars, barrier bars, alluvial fans and crevasse which characterize the reservoir rocks (sandstones) in the Niger Delta. At time window 2100-2200msec, anticlinal structures containing porous sand facies with little shale intercalations was observed again. At time window $2200 \mathrm{msec}$, water bearing sand facies (clean sandstone) was observed and at the bottom of the reservoir within time window 2300$2500 \mathrm{msec}$, the impedance was dominantly high which suggests the presence of shale facies at the bottom of the reservoir. Gas-oil contact (GOC) was observed between time window $2100-2200 \mathrm{msec}$ of the acoustic impedance section. These variations in acoustic impedance amplitude is due to lateral changes in lithofacies within the reservoir. The results obtained gave enhanced structural disposition of the reservoir and are important for accurate stratigraphic imaging interpretation to lower the risk in drilling of exploratory and development wells.
\end{abstract}

DOI: $\underline{\text { https://dx.doi.org/10.4314/jasem.v23i9.12 }}$

Copyright: Copyright (C) 2019 Eze et al. This is an open access article distributed under the Creative Commons Attribution License (CCL), which permits unrestricted use, distribution, and reproduction in any medium, provided the original work is properly cited.

Dates: Received: 22 June 2019; Revised: 16 September 2019; 24 September 2019

Keywords: Acoustic impedance, Seismic inversion, Model-based, Lithofacies.

INTRODUCTION: The inference of subsurface properties from measured data (seismic data) is identified with the solution of "inverse problem". Geophysical inversion is capable of handling different kinds of geophysical data such as seismic, potential field, borehole data e.t.c. (Yi Zhang et al., 2015; Tamuko 2008), and for every specific case of inversion the assumption is made that a specific physical law holds. According to Sheriff (2002), as cited by Okoli et al., (2018), inversion can be defined as a technique solving spatial distribution of parameters which could have produced an observed set of measurements. For the seismic case, the observation consists of the physical signature of a subsurface structure i:e the structure's reflected (or scattered) as a wave field due to a seismic source signal. Therefore, it is crucial to choose a proper model parameterization and a forward modeling procedure that can adequately describe the observations. For the acoustic case the defined set of parameters are "layer velocities and layer densities". Therefore, the choice of the right model is crucial and depends on the exploration problem at hand. The fundermental essence of seismic inversion is to retrieve a quantitative rock property from seismic reflection data that is characteristic to a reservoir ( $\mathrm{Yi}$ Zhang et al., 2015; Pendrel, 2006). The seismic reflection method ever since its discovery in the late 1920s, has and still remains one of the most effective tools in the search for hydrocarbons. Reflections are due to contrast in acoustic impedance in the subsurface caused by difference in physical properties of rocks which can be density and compressional wave velocity and can be explained in terms of lithology, porosity and porefill (Karbalaali et al., 2013; Hansen et al., 2008, Ukaigwe, 2000). The ultimate goal of the seismic method is to delineate structural and stratigraphic structures suitable for hydrocarbon accumulations. With advancement in technologies, the application of seismic data have extended to other areas such as stratigraphic imaging, pore-fluid estimation, and lithofacies differentiation e.t.c, and these applications have led to the discovery of huge oil and gas reserves often confined within structural and stratigraphic features. Lithofacies differentiation 
within a hydrocarbon reservoir unit is the lateral and vertical distribution of rock facies within the reservoir. This technique is aimed at improving reservoir characterization to optimize hydrocarbon production (Ofuyah et al., 2015).

In analyzing seismic facies (lithofacies), effort is made to retrieve rock properties from seismic data using the inversion technique so as to obtain meaningful results for reservoir characterization (Ahmed and John 2016; Parvaneh 2015). Unlike seismic reflection dataset (which is an interface property) acoustic impedance is a rock property and is the product of rock density and p-wave velocity. Acoustic impedance inversion involves conversion of seismic traces to a reflection coefficient time series, and then into an acoustic impedance trace (Parvaneh 2015; Jason et al., 2008; Lavergne and William, 1977; Lindseth, 1979). These impedance traces will help augment the accuracy of interpretation and correlation with properties measured in well logs. The ability to estimate acoustic impedance from seismic data increases the interpreters ability to discriminate between different lithofacies and fluid types (Ogagarue 2016; Jason et al., 2008; Duffaut et al., 2000), resulting in a detailed stratigraphic/reservoir imaging for improved hydrocarbon recovery. In this sense, impedance inversion can be considered a sophisticated method of integrating well logs and seismic data for lithofacies differentiation and reservoir characterization (Ogagarue and Alaminiokuma 2016; Ahmed and John 2016; Nadin and Kusznir 1995). The model based inversion technique converts seismic data to a pseudoacoustic impedance $\log$ at every trace. Acoustic impedance dataset is utilized in producing more accurate and detailed structural and stratigraphic interpretations than can be obtained from seismic (or seismic attribute) interpretation. This is an improvement over conventional seismic interpretation which relies on the seismic data alone to map geological structures suitable for hydrocarbon accumulation (Ogagarue and Alaminiokuma 2016; Parvaneh 2015; Jason et al., 2008). In many geological environments, acoustic impedance has a strong relationship to petrophysical properties such as porosity, lithology, and fluid saturation. This present study is aimed at applying a model-based inversion algorithm to invert acoustic impedance dataset from seismic data and interprete results for lithofacies discrimination.

The model-based acoustic impedance inversion is actualized based on the generalized linear inversion (GLI) reported by Cooke and Schneider (1983), as cited by Ogagarue and Alaminiokuma (2016); Parvaneh (2015); and Jason et al., (2008). The generalized linear inversion employs the Taylor series expansion;

$$
S(M)=S(M i)+\frac{\partial S(M i)}{\partial M} \Delta M+\cdots
$$

Where; $\mathrm{Mi}=$ initial model; $\mathrm{M}=$ real model; $\Delta \mathrm{M}=$ change in model parameters; $\mathrm{S}(\mathrm{M})=$ observed seismic trace, $\mathrm{S}(\mathrm{Mi})=$ synthetic seismic from initial model

The strength of the model-based inversion algorithm is its ability to reduce the difference $(\Delta S)$ between the observed seismic trace $\mathrm{S}(\mathrm{M})$ and the synthetic seismic $\mathrm{S}(\mathrm{Mi})$ obtained from the initial model (Ogagarue and Alaminiokuma 2016; Jason et al., 2008). The initial model incorporates low frequency information from local wells (Jason et al., 2008). The objective function is reduced by repetitive modification of the model which gives a reasonable solution if the initial guess model is within the region of global convergence of the objective function (Jason et al., 2008; Hampson and Russell, 1999). The Hampson-Russell strata theory is a highly evolved method that minimizes the following objective function:

$e=(T-w D L)$

2

Where $\mathbf{e}$ is the residual difference (in vector notation) between the seismic trace $\mathbf{T}$ and the trace resulting from the model data $\mathbf{w D L}$, where $\mathbf{w}$ is the convolutional wavelet matrix for an $n$ sample wavelet and $\mathrm{L}$ is a vector consisting of the logarithm of impedance for $m$ model samples and given as

$L(i)=\log Z(i)$

3

where $\mathrm{Z}(\mathrm{i})$ is the impedance model and $\mathbf{D}$ is an $m-1$ by $m$ derivative matrix where $m$ is the number of layers to be solved for and $m-1$ is the number of reflection coefficients (Ogagarue and Alaminiokuma 2016; Jason et al., 2008). The addition of the square of the errors is given by:

$e^{T} e=(T-w D L)^{T}(T-w D L)$

Using linear inverse theory (Jason et al., 2008; Aster et al., 2005), minimizing $\mathbf{e}^{\mathbf{T}} \mathbf{e}$ leads to the "normal equation" (with a stabilization factor, a) inserted we have:

$\left(\left(D^{T} w^{T} W D\right)+a I\right) L=D^{T} w^{T} T \quad 5$

However, rather than solving Equation (5) directly for $\mathbf{L}$, a solution estimate is found by repetitive refinement of a guess at the correct model until $\mathbf{e}^{\mathbf{T}} \mathbf{e}$ is minimized (Jason et al., 2008). An initial guess model is seeded in Equation (5) for $\mathbf{L}$ which includes the low frequency trend from regional wells (Ahmed and John 2016; Jason et al., 2008).

Conjugant gradient repetition of $\mathbf{L}$ then minimizes the error $\mathbf{e}^{\mathbf{T}} \mathbf{e}$. However, since the solution to Equation (5) is non-unique (an infinite number of models can minimize $\mathbf{e}^{\mathbf{T}} \mathbf{e}$ ), constraints are introduced that restricts the possible solutions (Jason et al., 2008; Hampson and Russell, 1999). These constraints are imposed on the upper and lower bounds for the impedance estimates (Yi Zhang et al., 2015; Jason et al., 2008). The algorithim enables the user to define the bounds 
as a percentage of the average impedance of the initial guess model and low frequency trend introduced in the initial guess model, is carried through to the final solution since low frequency data is generally not recorded in the seismic data. Also, high frequencies above the seismic bandwidth are carried through if they are not filtered away from the model prior to the inversion (Jason et al., 2008).

From the above precedings, a good model based inversion algorithm will produce high-quality acoustic impedance volumes from post-stack seismic data. The model was based solely on the calculated impedance at $\log$ resolution from a control well which was then extrapolated throughout the survey domian. The lowfrequency impedance data missing from the seismic data is derived from well logs (Ogagarue and Alaminiokuma 2016; Ahmed et al., 2016). To further adapt the model algorithm to fit the behaviour of real rocks in the subsurface, the inversion was constrained to allow a weighting factor between reducing the sparsity of the solution and reducing the disparity of the residual traces.

Geologic Setting: The field under study is XY field located in a transitional environment around Port Harcourt offshore of the Niger Delta. The Niger Delta is situated in the Gulf of Guinea in the West coast of Africa (Michele et al., 1999; Akpoyovbike 1978). The Niger Delta basin is a prolific hydrocarbon province that evolved in early tertiary times where rapid deposition and subsidence have occurred over time (Doust and Omatsola, 1990).

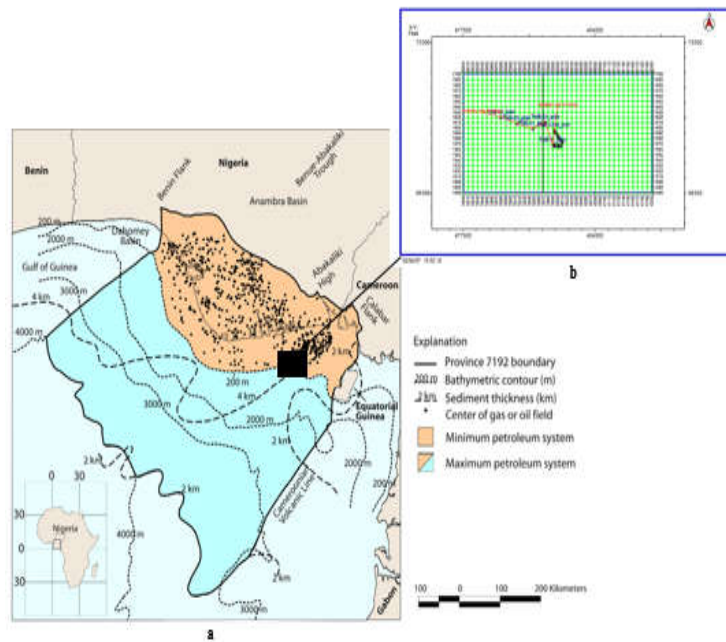

Fig 1(a): Index Map of Nigeria and Cameroon. Map of the Niger Delta showing province outline (Maximum petroleum system); bounding structural features, minimum petroleum system as defined by oil and gas field center points; 200, 2000, 3000, and $4000 \mathrm{~m}$ bathymetric contours; and 2 to $4 \mathrm{~km}$ sediment thickness (After Petro consultant, 1996a); Figure 1(b): Base map of study area showing the seismic survey grid and well locations (TMB-01 plan to TMB-06 plan in black circle). TMB-01 plan is the reference well.

This paper focuses on acoustic impedance inversion and interpretation of results for lithofacies differentiation within a reservoir interval. The study area is XY field located within the Niger Delta.

Collectively, the delta is known to have prograded over the subsidizing continental-oceanic lithospheric transition zone, and during the Oligocene spread into oceanic crust of the Gulf of Guinea (Orife and Avbovbo 1982; Short and Stauble 1967). Thickness of sediments in the region averages at $12 \mathrm{~km}$ covering a total area of about 140,000 $\mathrm{km}^{2}$ (Akpabio et al., 2014; Agbasi 2013; Alao et al., 2013). The early Niger Delta is interpreted as being a river-dominated delta, however the post-Oligocene delta is a typical wavedominated delta with well-developed shoreface sands, beach ridges, tidal channels, mangrove and freshwater swamps (Orife and Avbovbo 1982; Akpoyovbike 1978; Tamuko 2008).

It is one of the world's largest deltas and shows an overall upward transition from marine shales (Akata Formation) through a sand-shale paralic interval (Agbada Formation) to continental sands of the Benin Formation (Michele et al., 1999; Akpoyovbike 1978). Depending on relative sea level changes, local subsidence and sediment supply, the delta experiences episodes of regressions and transgressions (Nadin and Kusznir 1995; as cited by Tamuko 2008). The stratigraphic arrangement of the Niger Delta comprises of three wide lithostratigraphic units namely; a continental shallow massive sand sequence - the Benin Formation, a coastal marine sequence of alternating sands and shales - the Agbada Formation and a basal marine shale unit-the Akata Formation (Alao et al., 2013; Akpabio et al., 2014; Agbasi 2013). The Akata Formation consists of clays and shales with minor sand alternations (Alao et al., 2013). The sediments were deposited in prodelta environments, with sand percentage collectively less than $30 \%$ (Akpabio et al., 2014; Alao et al., 2013; Agbasi 2013). The Agbada Formation consists of alternating sand and shales representing sediments of the transitional environment comprising the lower delta plain (mangrove swamps, floodplain and marsh) and the coastal barrier and fluvio marine realms (Akpabio et al., 2014; Alao et al., 2013; Agbasi 2013). The sand percentage within the Agbada Formation varies from 30 to $70 \%$, which results from the large number of depositional off lap cycles. A complete cycle generally consists of thin fossiliferous transgressive marine sand, followed by an offlap sequence which commences with marine shale and continues with laminated fluvio marine sediments followed by barriers and/or fluviatile sediments ended by another transgression cycle (Alao et al., 2013; Ejedawe 1981; Weber and Daukoru 1975). The Benin Formation consists of high sand percentage (70-100\%) and forms the top layer of the Niger Delta depositional sequence (Alao et al., 2013). The massive sands were deposited in continental environment comprising the fluvial realms (braided and meandering systems) of the upper 
delta plain (Akpabio et al., 2014; Alao et al., 2013; Agbasi 2013). Petroleum occurs within the Agbada Formation of the Niger Delta basin however, several directional trends form an "oil-rich belt" having the largest field and lowest gas:oil ratio (Tamuko 2008; Michele et al., 1999; Akpoyovbike 1978; Ejedawe, 1981; Evamy et al., 1978; Doust and Omatsola, 1990). Hydrocarbon occurrence was originally ascribed to timing of trap formation relative to petroleum migration (earlier landward structures trapped earlier migrating oil) (Tamuko 2008; Michele et al., 1999).

\section{MATERIALS AND METHODS}

Materials: In this study, a suite of data which contains GR, density log, sonic log acquired in a well (control well) in XY field and post stack seismic volume passing through the well location was provided. The field contains six wells coded as TMB-01 to TMB-06 on the base map with TMB-01 (well W-01) acting as the refrence well. The well data in $\mathrm{W}-01$ covers a depth range of about $1850 \mathrm{~m}$ to $2350 \mathrm{~m}$. The seismic data contains 104 crosslines and reflections were observed from time window $2.0 \mathrm{sec}$ to $2.6 \mathrm{sec}$.

Checkshot correction and Well-to-seismic correlation: The initial step in the inversion procedure was checkshot correction of the p-wave sonic log to match the two-way-time of seismic data. After this, the well data was tied to the seismic data to procure a correction for the p-wave sonic velocity at the well location. The post stack seismic volume (in SEG-Y format) was loaded through the STRATA sub-program in HRS and well-01 (control well) was placed along cross line 37 on the post stack seismic volume.

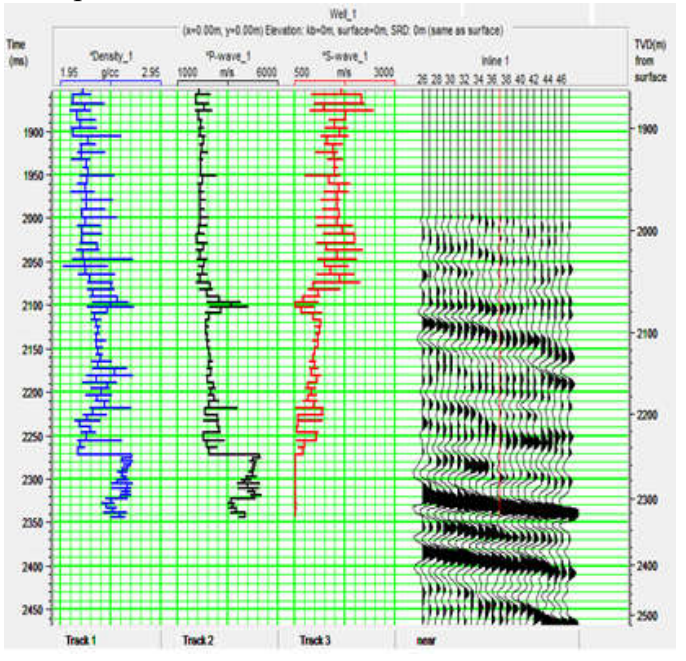

Fig 2: Well Log data showing Bulk density log (Track 1); P-wave sonic (Track 2); S-wave sonic (Track 3) and Seismic data

A Statistical wavelet of length $75 \mathrm{~ms}$ and about $65 \mathrm{~Hz}$ frequiency was extracted from the seismic data and convolved with density and sonic logs from well-01 to produce the synthetic seismogram. In an effort to improve the match between the synthetic and composite trace at the well location, the two traces were cross correlated twice (first and second correlation). A total of four reflections labelled as R1, R2, R3 and R4 were picked across the synthetic, composite and real seismic trace at points of sharpest crest amplitude. The synthetic seismogram was correlated to the composite trace (average seismic traces around the well location). The correlation process was carried out by selecting events on the synthetic trace and the corresponding event on the composite trace. The first correlation was done across the traces by clicking on the stretch option on HRS interface on the eLOG program; the maximum coefficient of correlation obtained was 0.5029 ( $\approx$ $50 \%)$. The second correlation yielded an improved correlation coefficient of about $0.6047(\approx 61 \%)$ across the synthetic, and composite seismic traces within the time window $2340 \mathrm{msec}$. Figure 7 shows the retain cross correlation curve for the first and second correlation and the correlation display for the three traces while figure 8 shows the final well-to-seismic correlation display.

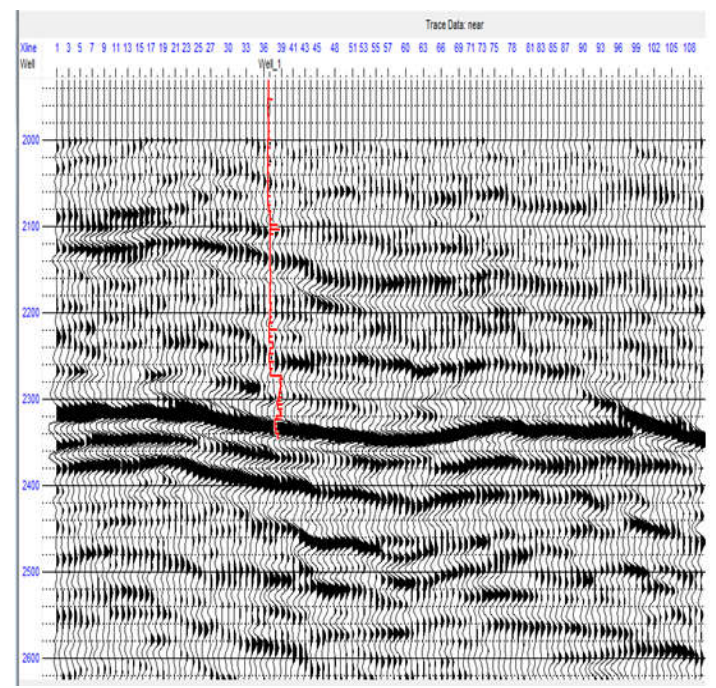

Fig 3: Well-01 placed on Seismic Section along crossline 37. The well runs from two-way-time $1900 \mathrm{msec}$ to $2340 \mathrm{msec}$ on the seismic section.

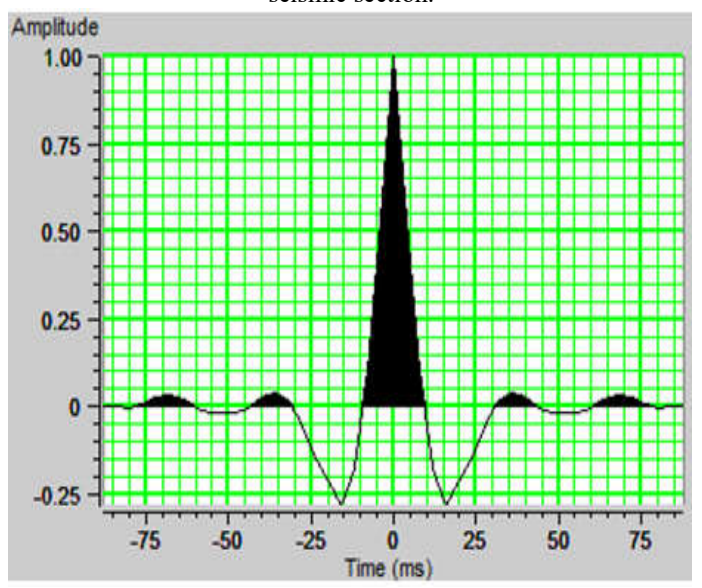

Fig 4: Statistical Wavelet of length $75 \mathrm{~ms}$ extracted from Seismic Data 


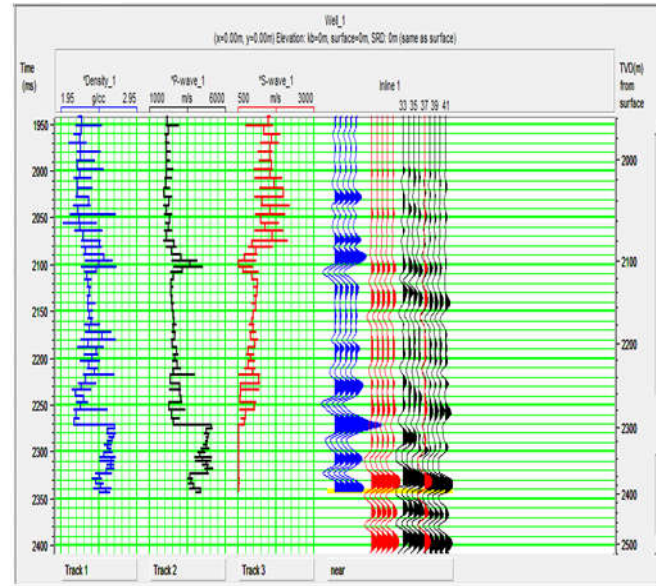

Fig 5: Synthetic seismogram (blue); Composite (red) and real seismic traces at the Well Location

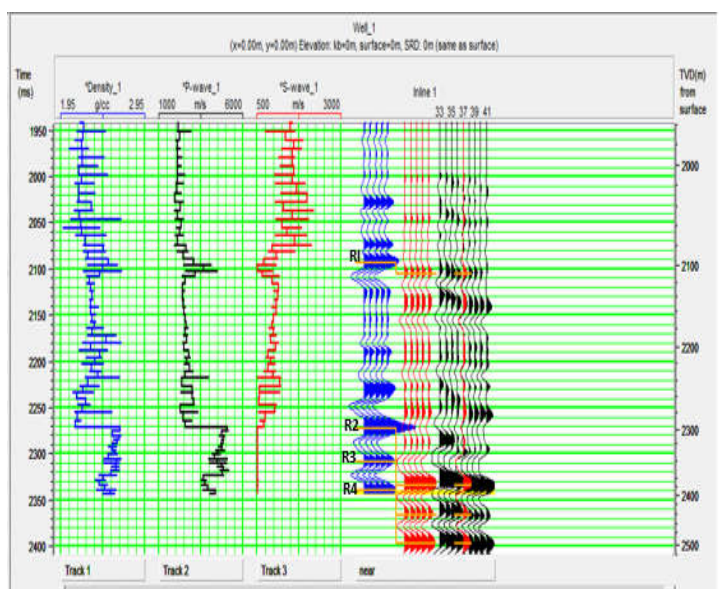

Fig 6: Picked Reflections in areas of Sharpest Amplitude across

the Synthetic, Composite and Seismic Traces.

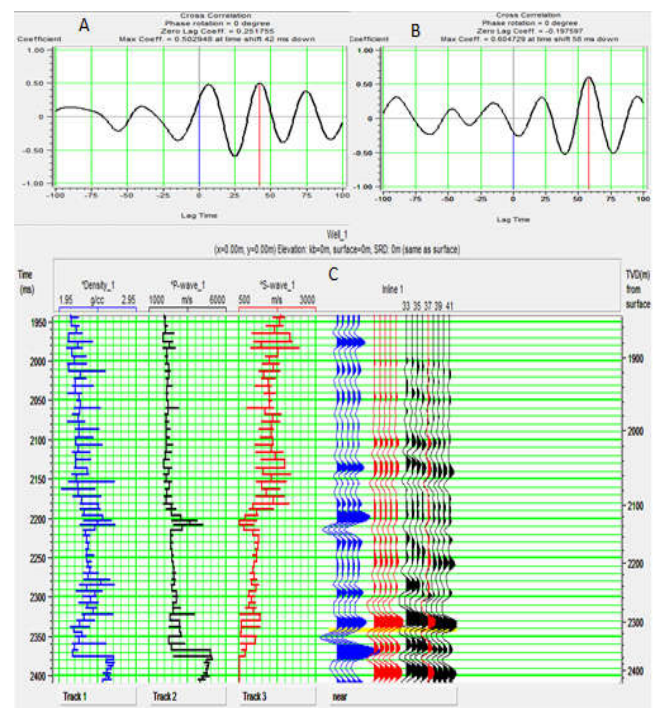

Fig 7: Well-to-seismic correlation: (a) First Cross Correlation Curve (b) Second Cross Correlation Curve (c) Correlation display showing the time window $2340 \mathrm{~ms}$ (yellow arrow) at which the three traces matches in their crest amplitude: syntheric traces (blue); composite traces (red); field seismic traces (black).

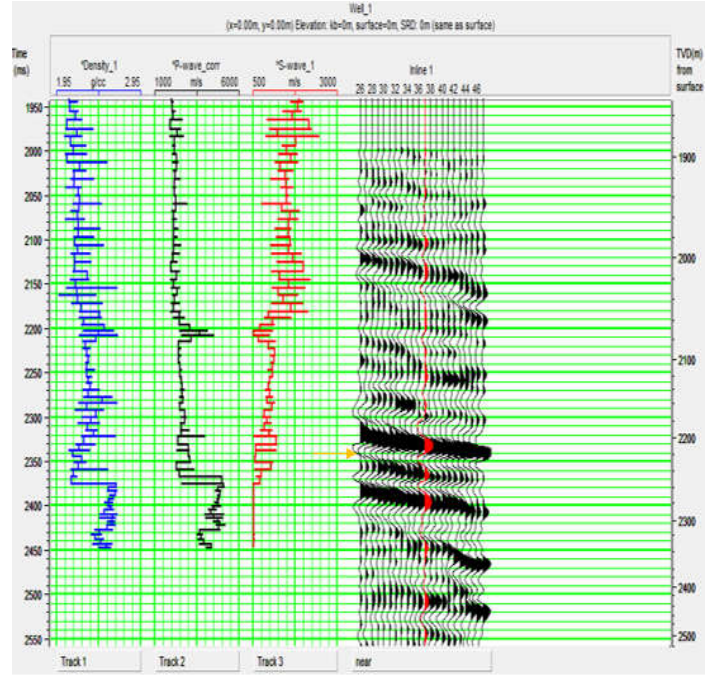

Fig 8: Final Well-to-Seismic correlation display

Initial Guess Impedance Model and Inversion: The initial Guess impedance model was created based on the calculated impedance at log resolution from the control well. The calculated well impedance ( $p$ impedance $\log$ ) was then extrapolated throughout the survey domain and was used as the guess model (Jason et al., 2008). In this study, five horizons with prominent amplitudes were picked at time window $2100 \mathrm{msec}, 2200 \mathrm{msec}, 2300 \mathrm{msec}, 2340 \mathrm{msec}$ and $2360 \mathrm{msec}$ for the seismic inversion. The picked horizons were carefully smoothed to provide prior geological information such as acoustic impedance of layers to improve the inversion process. Seismic data do not contain low frequencies (they are band-limited). Low frequency information is critical in quantitatively inverting acoustic impedance dataset and other reservoir properties sensitive to changes in lithofacies. This prevents the inverted impedance dataset from having the necessary impedance structure required to fit the behaviour of real rocks in the subsurface which is key to making good geological interpretation thus making lithofacies differentiation within the reservoir window difficult based on seismic inversion. To compensate for this, well logs (which contain low to very high frequency data) was used to add the low frequencies missing in the seismic band and to constrain our inversion. Also a high cut filter (low pass) of frequency $9 \mathrm{~Hz}$ was used in the initial guess model to include frequency bands below the seismic data. This low frequency model was corroborated with well logs and used as the initial guess model for the conjugate gradient perturbation of the impedance model (Jason et al., 2008). Finally, a model-based inversion solution was carried out on the entire $3 \mathrm{D}$ data volume. This process requires that the absolute amplitude of the wavelet must be known, and this is resolved by convolving the unscaled wavelet $\mathbf{W}$ with the reflecticity of the initial guess model (r) at well (W-01) and correlated with $\mathbf{W}^{\mathbf{T}}$ to give $\mathbf{W}^{\mathbf{T}} \mathbf{W r}$ (HRS Strata theory, 1999) to produce an inverted acoustic 
impedance cross section which was interpretaed for lithofacies differentiation.

\section{RESULTS AND DISCUSSION}

Figure 9 shows the initial P-impedance model with inserted corrected P-wave velocity log at well W-01. The different colours in the model shows variation in P-impedance amplitudes, ranging from 4075 to about $5847 \mathrm{~m} / \mathrm{s}^{*} \mathrm{~g} / \mathrm{cm}^{3}$

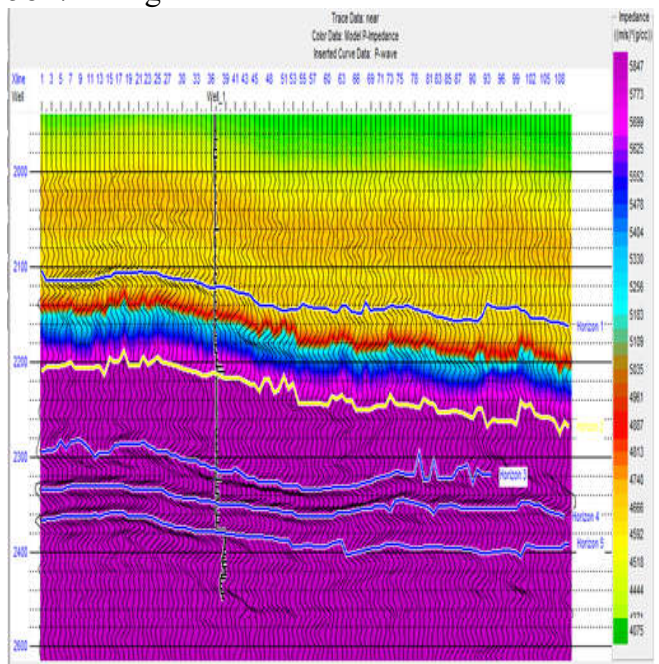

Fig 9: Initial Guess P-impedance model showing well W-01 location and inserted corrected P-wave velocity log from the well.

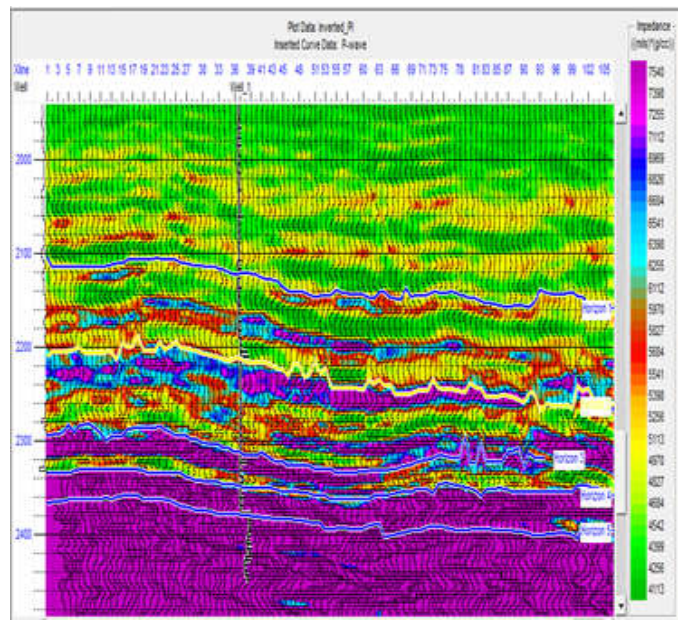

Fig 10: Cross-section of acoustic impedance at main reservoir. The section shows low-impedance amplitude at top of reservoir and high-impedance amplitude at the bottom of the reservoir

Figure 10 shows the P-impedance inversioin result with inserted P-wave velocity log across the five horizons. The figure shows lateral and vertical variations in acoustic impedance from top to bottom of the reservoir which depicts difference in lithofacies across the five horizons. The impedance section still contains trace wiggles of the seismic data and was detraces to improve the resolution of the final inverted section for detailed geological interpretation as illustrated in figure 11. Figure 11 shows the final inverted cross section of acoustic impedance (detraced and smoothened). The section shows acoustic impedance increasing from 4112 to about 7539 $\left(\mathrm{m} / \mathrm{sec}^{*} \mathrm{~g} / \mathrm{cm}^{3}\right)$ from top to bottom of the main reservoir. The colour variation indicates different acoustic impedance values which suggests different lithofacies within the reservoir interval. At the top portion of the section from time slice $1900-2100 \mathrm{msec}$ the impedance is dominantly low as indicated by the colour change from green to yellow with little red, this impedance trend suggest gas filled sand lithofacies (Lavergne et al., 1979).

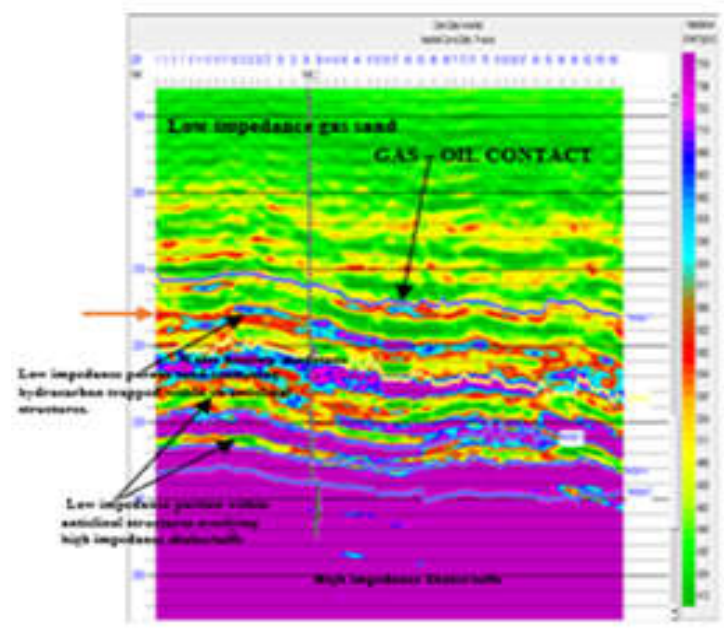

Fig 11: Final Inverted cross-section of acoustic impedance (Detraced and smoothened) to improve visualization.

Below time slice $2100 \mathrm{msec}$ (red arrow) there is variable impedance as shown by the colour band (red to light blue with little purple) within the anticlinal structures seen at this interval which suggests porous sand facies containing little shale intercalations (in purple), and is characteristic of sandstone reservoirs within the Agbada formation in the Niger Delta (Tamuko 2008). These sands were probably deposited through distributaries channel deposits, distributaries mouth bars, barrier bars, point bars, alluvial fans, overbank and crevasse which characterize the reservoir rocks (sandstones) in the Niger Delta; with a shallow - deep marine environment of deposition and as such prospective areas (with low impedance seen in red colour) trapped within the anticlinal structures seen between time slice 2100-2200msec would trap hydrocarbon. These areas are recommended for drilling of exploratory, appraisal, and development wells for optimal hydrocarbon production. At time slice $2200 \mathrm{msec}$ (horizon 2) we noticed a mixture of blue and purple colour which indicates slightly high impedance values and suggests water bearing sandstone (clean sandstone).

At the bottom portion of the section from time slice $2300-2500 \mathrm{msec}$ which is the base of the reservoir the acoustic impedance is dominantly high (purple colour) which suggests presence of shale lithofacies at the base 
of the sand reservoir (Lavergne et al., 1979). The low impedance portion seen overlying the high impedance zones (in purple) is another prospective area since it is trapped within anticlinal structures at time slice $2300 \mathrm{msec}$ along horizon 4. These variations in acoustic impedance values is due to lateral facies variation within the reservoir. Gas-oil contact (GOC) is seen between time slice $2100-2200 \mathrm{msec}$ of the impedance section. The results observed corresponds with the findings made by Eze et al., (2019) in their study on Spectral method of Lithofacies differentiation within a thin-sand reservoir unit using seismic and well data; where amplitude inversion of seismic data was used to derive rock attributes such as acoustic impedance, velocity, density and porosity. These attributes were subjected to lithofacies differentiation and three lithofacies were observed, interpreted as gas filled sands, oil sands and shale after Dobrin and Savit (1988) and were distributed laterally across the reservoir bed.

Conclusion: This study have applied a Model based inversion technique to invert an acoustic impedance structure required to fit the behaviour of rocks in the subsurface using post stack 3D seismic data, for the purpose of differentaiting the various lithofacies and to show lateral and vertical variations in rock property within the reservoir interval. The inversion results obtained in this study gave improved understanding on reservoir geometry, reservoir fluid types and hydrocarbon fairways. Prior knowledge of these can be incorporated into drilling decision for field development. The study have also contributed to the existing literatures on seismic inversion and presence of lateral continuity of sand lithofacies.

Acknowledgements: We wish to express our gratitude to CGG Geosoftware for providing the software used for the study.

\section{REFRENCES}

Agbasi, O E (2013). Estimation of water saturation using a modelled equation and Archies equation from wireline logs, Niger Delta Nigeria. IOSR J. Appl. Phy. 3 (4): 66-71

Ahmed H; John C (2016). Distinguishing gas-bearing sandstones reservoirs within mixed SiliciclasticCarbonate sequence using extended elastic impedance: Nile Delta, Egypt. Interp. 4 (4): 435 449.

Alao, PA; Ata, AI; Nwoke, CE; Chuo, YJ; Tzanis, A (2013). Subsurface and Petrophysical studies of Shaly-sand reservoirs targets in Apete field, Niger Delta, Hind. Geophy. 10: 1155.

Akpoyovbike AA (1978). Tertiary lithostratigraphy of Niger Delta, AAPG Bulletin. 62 (2): 295-300.
Akpabio I; Jothson CI; Okechukwu EA; Odunaya TO (2014). Petrophysical characterization of eight wells from wireline log, Niger Delta, Nigeria. Asian. J. Appl. Sci. 2 (1): 105.

Auster, RC; Borchers, B; Thurber, CH (2005). Parameter estimation and inverse problems. Elsevier Academic Press.

Cooke, D; Schneider, W (1983). Generalized inversion of reflection seismic data. Geophy. 48(6): 665676.

Ogagarue, DO; Alaminiokuma, GI (2016). Lateral Rock Property Prediction by Post Stack Acoustic Impedance Inversion: A case study from offshore Niger Delta. Int. J. of Sci. Basic and Appl. Research (IJSBAR). 26(3): 1-13.

Ogagarue, DO (2016). A comparative study of Acoustic and Elastic Impedance Seismic Models for Rock Property Prediction: An example from XYZ Field, Nigeria. Int. J. of Sci. Basic and Appl. Research (IJSBAR). 26(3): 24-34.

Dobrin MB; Savit, CH (1988). Introduction to Gephysical prospecting, $4^{\text {th }}$ edition, New-York, McGrawHill. 72-84.

Doust, H; Omatsola, E (1990). Niger Delta, in Edwards, JD; Santogrossi, PA eds; Divergent/passive Margin basins; AAPG Memoir 45: 239-248.

Duffaut, K; Alsos, T; Landro, M; Rogno, H; and AlNajjar, N (2000). Shear wave elastic impedance, The Leading Edge (TLE). 1222-1229.

Ejedawe, JE (1981). Patterns of incidence of oil reserves in Niger Delta Basin. AAPG Bulle. 65: 1574-1585.

Evamy, BD; Haremboure, J; Kammerling, R; Knaap, WA; Molloy, FA; Rowlands, PH (1978). Hydrocarbon habitat of tertiary Niger Delta. AAPG Bulletin. 62(1): 1 - 39.

Eze, S; Emujakporue, GO; Ofuyah, W; Nnorom, LS (2019). A Spectral method of Lithofacies differentiation within a hydrocarbon reservoir unit using seismic and well data from Tomboy Field Niger Delta. J. of Envir. \& Earth Sci. 9(3). DOI: 10.7176/JEES: 146-169.

Hamson-Russell Ltd (1999). The theory of Strata program.

Hansen, TM; Mosegaard, K; Pedersen-Tatalovic, R; Uldall, A; Jacobsen, NL (2008). Attribute- 
guided well-log interpolation applied to lowfrequency impedance estimation. Geophysics. 73(6). November-December 2008: 8395.10.1190/1.2996302.

Jason, M; Crank, MC; Don, L (2008). Acoustic impedance inversion and $\mathrm{Co}_{2}$ flood detection at the Alder flats ECBM Project. CREWES Research Report. 20.

Karbalaali, H; Shadizadeh, SR; Ali, R (2013). Delineating hydrocarbon bearing zones using Elastic Impedance Inversion; A persian Gulf example. Iranian. J. Oil and Gas science and technology. 2 (2): 8-19.

Lavergne, M; Becquey, M; William, C (1979). Acoustic impedance logs computed from seismic traces. Proceedings at the $46^{\text {th }}$ SEG international annual meeting. 44(9): 1485-1501.

Lavergne, M; William, C (1977). Inversion of seismograms and pseudo-velocity logs. Geophys. Prosp. 25: 232-250.

Lindseth, RO (1979). Synthetic sonic logs-a process for stratigraphic interpretation. Geophysics. 44(1): 3-26.

Michele, LWT; Ronald, RC; Michael, EB (1999). The Niger Delta Petroleum system; Niger Delta province, Nigeria, Cameroon and Equitorial Guinea. Africa Open file report: 50-51.

Nadin, PA; Kusznir, NJ (1995). Palaeocene uplift and Eocene subsidence in the Northern North Sea Basin from 2D forward and reverse stratigraphic modelling. J. of the Geolo. Society. 152 (5): 833848.

Ofuyah, W; Orji, O; Eze, S (2015). The Application of Spectral Decomposition to 3-D Seismic Data over ' $X$ '-Oil Field, Niger Delta: Geosciences. 5: 86-99.

Orife, JM; Avbovbo, AA (1982). Stratigraphic and Unconformity traps in the Niger Delta.
Okoli, EA; Onyekuru, SI; Agbasi, OE; Zaidoon, TA (2018). Application of Model-based inversion technique in a field in the coastal swamp depobels, Niger Delta. Int. J. Adv. Geosciences. 6 (1): $122-126$.

Parvaneh, K (2015). Structure-constrained relative acoustic Impedance using Stratigraphic Coordinates. Geophysics. 80 (3): 63-67.

Pendrel, J (2006). Seismic inversion -a critical tool in reservoir characterization, Scandinavian Oil-Gas Magazine. 5(6): 19-22.

Petroconsultants, (1996). Petroleum exploration and production database: Houston

Sheriff, RE (2002). Encyclopedic Dictionary of Applied Geophysics. Society of Exploration Geophysics, Tulsa, Oklahoma, USA, 13 editions.

Short, KC; Stauble, AJ (1967). Outline of geology of Niger Delta. AAPG Bulletin. 51(5): 761 - 779.

Tamuko, OJ (2008). 3D Seismic structural interpretation and Petrophysical Evaluation of X- field, Niger Delta Basin, Nigeria, B.Tech Unpublished Project, Federal University of Technology Akure (FUTA).

Ukaigwe, NF (2000). A first course in Seismic exploration, Eddy-Joe publishers, Nigeria Ughelli, Port Harcourt. $2^{\text {nd }}$ ed: 85-86 \& 367-372.

Weber, KJ; Daukoru, EM (1975). Petroleum Geology of the Niger Delta. Proceedings of the 9th World Petroleum Congress Tokyo. Appl. Sci. publishers, Ltd, London. 2: 202-221.

Yi Zhang; Jiangwo, Y; Fei Li; Chao, C; Bao, M; Shuanggen, J; James HD (2015). A new bound constraints method for 3D Potential field data Inversion using Lagrangian Multipliers. Geophys. J. Int. 2(1): 267-275. 